Arq. Bras. Med. Vet. Zootec., v.59, n.6, p.1583-1585, 2007

\title{
Comunicação
}

[Communication]

\section{Infecção em cão por Brucella abortus: relato de caso}

\author{
[Brucella abortus infection in dog: case report] \\ J. Megid ${ }^{1}$, V.R. Salgado ${ }^{1}$, L.B. Keid ${ }^{2}$, A.K. Siqueira ${ }^{1}$, C.E. Meirelles ${ }^{3}$, D.M. Moretti ${ }^{3}$ \\ ${ }^{1}$ Faculdade de Medicina Veterinária e Zootecnia - UNESP \\ Distrito de Rubião Júnior s/n, \\ Caixa Postal 560, \\ 18618-000 - Botucatu, SP \\ ${ }^{2}$ Faculdade de Medicina Veterinária e Zootecnia - USP - São Paulo, SP \\ ${ }^{3}$ Centro Veterinário de Bauru - Bauru, SP
}

A brucelose canina caracteriza-se como doença infectocontagiosa crônica, de distribuição mundial, que acomete os canídeos domésticos e silvestres e o homem. A doença é considerada zoonose, com caráter ocupacional, manifestandose, no homem, sob a forma de febre, mialgias, cefaléia, dermatite, linfadenopatia e ocasionalmente poliartrite (Acha e Szyfres, 2001).

Nos cães, a doença tem como principal agente etiológico a Brucella canis (Carmichael e Greene, 1998), porém há relatos de infecção por Brucella abortus, Brucella suis e Brucella melitensis (Bicknell et al., 1976; Prior et al., 1976; Sandoval et al., 1976; Barr et al., 1986; Miranda et al., 2005).

A infecção natural de cães por $B$. abortus é de ocorrência esporádica e resulta do contato estreito de cães, geralmente de zona rural, com bovinos infectados. Os cães infectam-se por ingestão de produtos de origem animal in natura, contato ou ingestão de tecidos animais, restos placentários ou de fetos abortados contaminados (Carmichael e Greene, 1998; Azevedo et al., 2003; Miranda et al., 2005). Esta espécie parece ser mais resistente à infecção por brucelas lisas, sendo raras as manifestações clínicas decorrentes da infecção (Azevedo et al., 2003). Em associação, entretanto, à bacteremia transitória, alguns animais podem apresentar linfadenopatia, abortamentos, orquites, epididimite e lesões articulares (Bicknell et al., 1976).

A identificação dos cães doentes é importante, pois esses animais constituem fontes de infecção, uma vez que podem eliminar o agente no ambiente pela urina, por ejaculados, por secreções vaginais, por fetos abortados ou pelas fezes (Forbes, 1990; Baek et al., 2003). A presença persistente da B. abortus em descargas vaginais de cães por tempo superior a 42 dias depois do parto ou abortamento foi descrita por Baek et al. (2003). Essa descarga, juntamente com restos de abortos dos cães doentes, é o material de maior risco na transmissão do agente para os próprios cães e para animais de produção (Forbes, 1990).

Forbes (1990) considerou a excreção urinária e fecal de $B$. abortus nos cães como sendo um evento de pouca importância para a disseminação da doença, em razão da eliminação ser incomum e de curta duração. Ainda, segundo o autor, o baixo número de microrganismos presentes nessas vias de eliminação e a resistência dos animais ao número reduzido de microrganismos contribuem para essa hipótese.

No Brasil, alguns pesquisadores encontraram anticorpos contra B. abortus em soros de cães (Sandoval et al., 1976; Azevedo et al., 2003; Almeida et al., 2004). Em virtude dos poucos

Recebido em 15 de maio de 2007

Aceito em 19 de setembro de 2007

Email: jane@fmvz.unesp.br 
relatos da enfermidade por B. abortus em cães, especialmente associados a sintomas clínicos, e da importância desses animais como fonte de infecção no contexto de saúde pública, relata-se o diagnóstico de infecção por $B$. abortus em cão macho da raça Boxer, de sete anos e meio de idade, procedente de uma propriedade rural da cidade de Bauru-SP, co-habitante com bovinos e cães errantes de outras propriedades.

O animal foi atendido no Centro Veterinário de Bauru com sintomas de salivação e vômitos. Ao exame físico, constataram-se no membro posterior esquerdo uma ferida exsudativa com hiperqueratose, aumento de volume com ligeiro aumento de sensibilidade no testículo esquerdo e diminuição do testículo direito, de onde se coletou material por citologia aspirativa com agulha fina.

A associação dos dados epidemiológicos à presença de sinais clínicos compatíveis com brucelose, a saber, orquite e atrofia testicular, levou a suspeita da enfermidade, procedendo-se a colheita de sangue para realização de sorologia, além de urina e sêmen.

No soro, submetido às provas de soroaglutinação rápida (RSAT), com $\quad \mathrm{o}$ Kit $\quad \mathrm{D}-\mathrm{Tec} \AA \quad \mathrm{CB}$ (Badakhsh et al., 1982) e imunodifusão em gel de ágar (IDGA) (Myers e Siniuk, 1970) com antígeno de $B$. ovis, o resultado foi negativo em ambas as provas. Paralelamente, foram realizadas provas de soroaglutinação rápida com antígeno acidificado tamponado (ATA), soroaglutinação lenta (SAL) e prova do 2Mercaptoetanol (2-ME) com o uso de antígeno de $B$. abortus, com resultados positivos e títulos de 200 na SAL e 2-ME. Para avaliar o perfil sorológico do animal, foram realizadas duas colheitas de sangue, intercaladas de 30 dias, seguidas por uma colheita uma semana após, e uma última, 45 dias depois. Os resultados foram os mesmos em todas elas.

Diversas tentativas de isolamento do agente foram realizadas a partir do sangue, dos aspirados testiculares, do sêmen e da urina, todos em ágar sangue ovino (5\%) desfibrinado por $96 \mathrm{~h}$ a $37^{\circ} \mathrm{C}$, em atmosfera de $10 \%$ de $\mathrm{CO}_{2}$, com resultados negativos.

Os espécimes clínicos foram também submetidos à reação em cadeia pela polimerase (PCR) (Romero et al., 1995). A extração de DNA de Brucella spp. foi realizada de acordo com o protocolo descrito por Vieira (2004). Foram empregados os primers $\mathrm{B}_{4} / \mathrm{B}_{5}$ desenhados por Baily et al. (1992), a partir do gene que codifica uma proteína imunogênica de $31 \mathrm{kDa}$ de $B$. abortus.

A falha no isolamento do agente nos cultivos microbiológicos e a detecção em somente uma das amostras de urina por meio da reação de PCR são concordantes com o descrito por Pidgeon et al. (1987) e Forbes (1990).

Ressalta-se, no presente relato, a identificação de brucelose por B. abortus em cão, associada com sintomatologia clínica, sorologia persistente e presença do DNA bacteriano em urina e sangue, caracterizando o cão como possível fonte de infecção da doença em rebanhos com histórico de brucelose.

Palavras-chave: cão, orquite, Brucella abortus, sorologia, microbiologia, PCR

\begin{abstract}
Brucella abortus infection is reported in a dog from a rural area that presented at clinical evaluation left testicular enlargement and right testicular decrease. Serum resulted negative to rapid agglutination test and agar gel immunodifusion with Brucella ovis antigen but positive to buffered plate agglutination test, tube agglutination test and 2- Mercapthoetanol with B. abortus antigen. Brucella isolation was negative in blood, testicular material, semen and urine. Brucella DNA was detected in PCR from urine and blood.
\end{abstract}

Keywords: dog, orchitis, Brucella abortus, serology, microbiology, PCR

®Symbiotics Co - USA 


\section{REFERÊNCIAS BIBLIOGRÁFICAS}

ACHA, P.N.; SZYFRES, B. Zoonosis y enfermedades transmisible comunes al hombre y a los animales brucellosis. 3.ed. Washington: OPS/OMS, 2001. p.28-56 (Publicación Cientifica y Tecnica, 580).

ALMEIDA, A.C.; SANTORELLI, A.; BRUSADELLI, R.M.Z. et al. Soroepidemiologia da brucelose canina causada por Brucella canis e Brucella abortus na cidade de Alfenas, MG. Arq. Bras. Med. Vet. Zootec., v.56, p.275-276, 2004.

AZEVEDO, S.S.; BATISTA, C.S.A.; ALVES, C.J. et al. Ocorrência de anticorpos contra Brucella abortus em cães errantes da cidade de Patos, Estado da Paraíba, Brasil. Arq. Inst. Biol., v.70, p.499-500, 2003.

BADAKHSH, F.F.; CARMICHAEL, L.E.; DOUGLASS, J.A. Improved rapid slid agglutination test for presuntive diagnosis of canine brucellosis. J. Clin. Microbiol., v.15, p.286-289, 1982.

BAEK, B.K.; LIM, C.W.; RAHMAN, M.S. et al. Brucella abortus infection in indigenous Korean dogs. Can. J. Vet. Res., v.64, p.312-314, 2003.

BAILY G.G.; KRAHN, J.B.; DRASAR, B.S. et al. Detection of Brucella melitensis and Brucella abortus by DNA amplification. J. Trop. Med. Hyg., v.95, p.271-275, 1992.

BARR, P.C.; EILTS, B.E.; ROY, A.F. et al. Brucella suis biotype 1 infection in a dog. J. Am. Vet. Med. Assoc., v.186, p.686-687, 1986.

BICKNELL, S.R.; BELL, R.A.; RICHARDS, P.A. Brucella abortus in the bitch. Vet. Rec., v.99, p.85-86, 1976.
CARMICHAEL, L.E.; GREENE, C.E. Canine Brucellosis. In: GREENE, C.E. (Ed). Infections disease of the dog and cat. 2. ed. Philadelphia : W.B. Saunders, 1998. p.248-257.

FORBES, L.B. Brucella abortus infection in 14 farm dogs. J. Am. Vet. Med. Assoc., v.196, p.911916, 1990.

MIRANDA, K.L.; COTTORELLO, A.C.P.; POESTER, F.P. et al. Brucelose canina. Cad. Tec. Vet. Zootec., n.47, p.66-82, 2005.

MYERS, D.M.; SINIUK, A.A. Preliminary report on the development of a diffusion in gel method for the diagnosis of ram epididymits. Appl. Microbiol., v.19, p.335-337, 1970.

PIDGEON, G.L.; SCANLAN, C.M.; MILLER, W.R. et al. Experimental infection of dogs with Brucella abortus. Cornell Vet., v.77, p.339-347, 1987.

PRIOR, M.G. Isolation of Brucella abortus from two dogs in contact with bovine brucelosis. Can. J. Comp. Med., v.10, p.117-118, 1976

ROMERO, C.; GAMAZO, C.; PARDO, M. et al. Specific detection of Brucella DNA by PCR. J. Clin. Microbiol., v.33, p.615-617, 1995.

SANDOVAL, L.A.; CONRADO RIBEIRO, L.O.; AMARAL, L.B.S. et al.. Incidência da Brucelose canina na cidade de São Paulo. Biológico, v.42, p.128-132, 1976.

VIEIRA, N.R. Desenvolvimento de uma reação em cadeia pela polimerase (PCR) para detecção de Brucella spp. em amostras de sangue de cães naturalmente infectados. 2004. 92f. Dissertação (Mestrado) - Faculdade de Medicina Veterinária e Zootecnia, Universidade de São Paulo, São Paulo. 